Original Research Paper

\title{
Penyuluhan Gerakan Makan Ikan Laut Sebagai Upaya Peningkatan Gizi Di SMPN 2 Gunungsari Kabupten Lombok Barat
}

\author{
Mahrus $^{1 *}$, Lalu Zulkifli' ${ }^{1}$, Dewa Ayu Citra Rasmi' ${ }^{1}$, Prapti Sedijani', Syamsul Bahri ${ }^{1}$ \\ ${ }^{1}$ Program Studi Pendidikan Biologi Fakultas Keguruan dan Ilmu Pendidikan, Universitas Mataram
}

*Corresponding Author:

Mahrus, Program Studi

Pendidikan Biologi

Fakultas Keguruan dan

Ilmu Pendidikan,

Universitas Mataram,

Indonesia;

Email:

mahrus@unram.ac.id

\begin{abstract}
Abstrak: Penyuluhan gerakan makan ikan laut sebagai upaya peningkatan gizi di SMPN 2 Gunungsari Kabuapten Lombok Barat bertujuan untuk meningkatkan kesadaran masyarakat akan pentingnya ikan laut sebagai salah satu sumberdaya yang sangat penting sebagai penopang dalam memperbaiki gizi masyarakat. Materi penyuluhan difokuskan pada khasiat mengkonsumsi ikan laut untuk kesehatan kepada guru-guru, dan selanjutnya diteruskan kepada para siswa baik sebelum, sedang dan sesudah jam pembelajaran berlangsung, kemudian siswa menyampaikannya kepada orang tua dan keluarganya. Penyadaran guru dan siswa tentang betapa pentingnya gizi dalam masa pertumbuhan dan mengajak masyarakat untuk gemar memakan ikan sebagai upaya perbaikan gizi masyarakat merupakan kegiatan yang sudah diprogramkan pemerintah orde baru sampai sekarang ini, dengan harapan membentuk manusia Indonesia yang berkualitas. Sentuhan guru sangat dibutuhkan untuk mensosialisasikan gerakan makan ikan karena guru setiap saat dapat menyampaikannya kepada siswa baik ketika sedang mengajar di kelas maupun di luar kelas. Guru di depan para murid sebagai orang yang digugu dan ditiru memiliki peranan yang sangat penting di dalam menyampaikan pesan gerakan makan ikan, oleh karena itu kegiatan pengadian ini orang pertama yang diberikan pemahaman tentang pentingnya mengkonsumsi ikan untuk kesehatan tubuh adalah guru. Selanjutnya guru diharapkan akan menyampaikannya kepada murid dan murid akan menyampaikannya kepada orang tua dan keluarga di rumah. Melalui program ini diharapkan kegemaran masyarakat terhadap gemar makan ikan semakin meningkat, sehingga upaya menciptakan kondisi masyarakat yang sehat dan berkualitas dapat terwujud di masa depan. Sekolah sebagai salah satu media yang efektif untuk mensosialisasikan pentingnya mengkonsumsi ikan untuk kesehatan dan kecerdasan anak.Tanggapan guru sebagai kelompok sasaran adalah sangat positif. Mereka baru pertamakali menerima materi pengabdian semacam ini meskipun pernah mendapatkan informasi ini baik melalui media cetak maupun elektronik. Berdasarkan pada pengalaman yang diperoleh selama proses kegiatan pengabdian dilakukan, anggota tim menyarankan: semua pihak terkait, terutama perguruan tinggi melalui Lembaga Penelitian dan Pengabdian Kepada Masyarakat perlu melakukan penelitian dan pemberdayaan masyarakat dengan program Gemar makan ikan.
\end{abstract}

Kata Kunci: Gizi, Ikan laut, Omega-3, Gemar makan ikan, Kesehatan

\section{Pendahuluan}

Perhatian para ahli kesehatan dunia sekarang ini pada ikan laut sangat serius, karena ikan tersebut sebagai sumber protein murah dan memiliki kandungan omega-3 tinggi yang sangat diperlukan untuk kesehatan manusia (Rebah et al., 2010; Dorval et al., 2011). Manfaat Omega-3 sangat baik bagi kesehatan manusia seperti mencegah penyakit jantung koroner, diabetes, kanker, dan berbagai penyakit lainnya serta berperan penting dalam sistem syaraf, otak, mata, dan lain lainnya (Monroig et al., 2011; Sayanova et al., 2011; Calder, 2012; Deckelbaum et al., 2012).

Upaya pemeliharaan kesehatan masyarakat saat ini merupakan hal yang perlu mendapat perhatian yang sangat penting oleh pemerintah. Sekitar lima juta balita di Indonesia teridentifikasi 
kekurangan gizi. Hal ini dikarenakan asupan makanan yang dikonsumsi kurang bergizi dan rendahnya daya beli masyarakat termasuk minimnya ketersediaan bahan pangan serta kurangnya pengetahuan masyarakat tentang pentingnya menjaga kesehatan sejak dini hingga masa tua. Gizi merupakan unsur yang sangat penting dalam tubuh manusia, dan dengan gizi yang baik, akan membuat tubuh menjadi segar dan dapat melakukan aktivitas dengan baik. Gizi harus terpenuhi sejak anak, karena gizi selain penting untuk pertumbuhan badan, juga penting untuk perkembangan otak. Untuk itu, orang tua harus mengerti dengan baik kebutuhan gizi anak agar anak tidak mengalami kurang gizi dan tidak gampang sakit. Selain itu, orang tua juga harus membiasakan anak untuk gemar memakan ikan. Dibanding dengan daging hewan lain, ikan merupakan makanan yang mudah dicerna oleh tubuh, sehingga ikan dapat dikonsumsi oleh semua golongan masyarakat, baik balita, anak-anak, remaja dan orang dewasa maupun orang tua.

Sebagian besar siswa SMPN 2 Gunungsari memiliki pengetahuan tentang pentingnya peningkatan gizi sejak dini masih terbatas, sementara masa anak-anak adalah masa pertumbuhan yang membutuhkan asupan gizi lebih agar pertumbuhannya optimal dan meningkatkan kecerdasan pada tiap individu. Demikian juga halnya dengan guru-guru di SMPN 2 Gunungsari memiliki pemahaman gizi yang relatif terbatas terlebih lagi pemahaman tentang ikan laut sebagai sumber gizi (terutama protein) yang paling baik dan aman, meskipun mereka sering mendengar dan membaca tentang manfaat ikan terutama Omega-3 ikan yang sangat bermanfaat bagi kesehatan manusia, terutama dalam mencegah berbagai macam penyakit dan untuk meningkatkan kecerdasan.

Sekolah sebagai salah satu media yang efektif untuk mensosialisasikan pentingnya mengkonsumsi ikan untuk kesehatan dan kecerdasan anak, tentunya sentuhan guru sangat dibutuhkan untuk mensosialisasikan gerakan makan ikan karena guru setiap saat dapat menyampaikannya kepada siswa baik ketika sedang mengajar di kelas maupun di luar kelas. Guru di depan para murid sebagai orang yang digugu dan ditiru memiliki peranan yang sangat penting dalam menyampaikan pesan gerakan makan ikan. Oleh karena itu dalam kegiatan pengadian ini orang pertama yang diberikan pemahaman tentang pentingnya mengkonsumsi ikan untuk kesehatan tubuh adalah guru. Selanjutnya guru diharapkan akan menyampaikannya kepada siswa/murid dan murid akan menyampaikannya kepada orang tua dan keluarga di rumah. Melalui program gerakan makan ikan laut diharapkan keasadaran akan pentingnya ikan laut sebagai sumber gizi penting semakin meningkat, sehingga uapaya menciptakan kondisi masyarakat yang sehat dan berkualitas dapat terwujud di masa depan.

Berdasarkan analisis situasi diatas, focus masalahnya terletak pada kurangnya pengetahuan anggota masyarakat termasuk para guru tentang pentingnya mengkonsumsi ikan sejak dini. Sentralnya peran guru di masyarakat pedesaan sebagai agen informasi dan transformasi Iptek dan budaya, maka sasaran utama dalam pengabdian ini adalah guru, yang pada gilirannya dapat mensosialisasikannya pada siswa-siswanya yang pada akhirnya dengan mengajak keluarga dan masyarakat sekitarnya tentang pentingnya mensosialisasi ikan laut yang harganya relative rendah dibandingkan daging. Jadi rumusan masalah pada kegiatan pengabdian adalah bagaiamana meningkatkan gerakan makan ikan laut di SMPN 2 Gunungsari melalui penyuluhan guru-guru.

\section{Metode Pelaksanaan}

Program kegiatan penyuluhan gemar makan ikan pada guru-guru SMPN 2 Gunungsari ini bertujuan sebagai berikut: 1) mensosialisasikan khasiat mengkonsumsi ikan laut untuk kesehatan kepada guru-guru, dan selanjutnya diteruskan kepada para siswa ketika pembelajaran berlangsung, kemudian siswa menyampaikannya kepada orang tua dan keluarganya; 2) menyadarkan para guru betapa pentingnya gizi dalam masa pertumbuhan dan mengajak masyarakat untuk gemar memakan ikan sebagai upaya perbaikan gizi masyarakat serta memperkenalkan berbagai olahan makanan yang berbahan dasar ikan dengan biaya yang cukup ekonomis dan mudah diolah.

Manfaat yang diharapkan dari kegiatan pengabdian ini adalah: 1) sebagai informasi praktis kepada guru sebagi anggota masyarakat tentang upaya meningkatkan derajat kesehatan masyarakat khususnya guru dan siswa. 2) bahan rujukan bagi 
pemerintah khsusnya Dinas Kelautan dan Perikanan, dan Dinas Kesehatan baik provinsi maupun kabupaten dalam mensosialisasikan gemar makan ikan laut sejak dini sebagai upaya peningkatan gizi.

Pelaksanaan kegiatan pengabdian ini dilaksanakan pada hari Sabtu, 1 Nopember 2014, bertempat di Ruag Guru SMPN 2 Gunugsari, Lombok Barat. Sekolah ini dipilih sebagai lokasi kegiatan dengan beberapa pertimbangan, diantaranya adalah: lokasi sekolah jauh dari laut dan pusat kota $(25 \mathrm{~km})$, kondisi ekonomi orang tua siswa menengah ke bawah (kategori miskin), Jumlah murid jauh lebih sedikit dibandingkan dengan sekolah lain, rata-rata murid yang masuk setiap tahunnya berjumlah sekitar 40 orang (2 kelas), motivasi belajar siswa untuk datang ke sekolah relatif rendah yang ditunjukkan dengan tingkat kehadiran siswa setiap minggunya rata-rata kurang dari $80 \%$.

Sekolah sebagai salah satu media yang efektif untuk mensosialisasikan pentingnya mengkonsumsi ikan untuk kesehatan dan kecerdasan anak. Sentuhan guru sangat dibuthkan untuk mensosialisasikan gerakan makan ikan karena guru setiap saat dapat menyampaikannya kepada siswa baik ketika sedang mengajar di kelas maupun di luar kelas. Guru di depan para murid sebagai orang yang digugu dan ditiru memiliki peranan yang sangat penting di dalam menyampaikan pesan gerakan makan ikan. Oleh karena itu kegiatan pengadian ini orang pertama yang diberikan pemahaman tentang pentingnya mengkonsumsi ikan untuk kesehatan tubuh adalah guru. Selanjutnya guru diharapkan akan menyampaikannya kepada siswa/murid dan murid akan menyampaikannya kepada orang tua dan keluarga di rumah. Melalui program ini diharapkan kegemaran masyarakat terhadap gemar makan ikan semakin meningkat, sehingga uapaya menciptakan kondisi masyarakat yang sehat dan berkualitas dapat terwujud di masa depan nantinya.

Kelompok yang menjadi khalayak sasaran dalam kegiatan ini adalah para guru. Selanjutnya pemahaman manfaat makan ikan laut bagi kesehatan akan diteruskan kepada para siswa ketika pembelajaran berlangsung, kemudian siswa menyampaikannya kepada orang tua dan keluarganya, serta masyarakat sekitarnya. Sesungguhnya target yang diharapkan dari khalayak sasaran ini adalah para guru mengetahui pentingnya memakan ikan untuk peningkatan kesehatan dan kesejahteraan masyarakat.

Metode yang digunakan pada kegiatan pengabdian ini adalah: ceramah tentang ikan laut sebagai sumber makan yang paling baik dan aman untuk kesehatan tubuh manusia, diskusi dan Tanya jawab. Sebelum kegiatan pengabdian ini dilaksanakan, terlebih dahulu dilakukan beberapa tahap kegiatan, diantaranya adalah: Pertama, observasi Pendahuluan yamg dilakukan untuk mengetahui keadaan riil sekolah, meliputi sosialekonomi, kebudayaan, serta permasalahan yang ada. Observasi ini bertujuan mendapatkan gambaran mengenai materi penyuluhan dan metode penyampaian yang tepat serta efektif. Kedua, menjalin kerjasama dengan pihak skolah yang dilakukan untuk mendukung kesuksesan jalannya program. Kerjasama ini meliputi kerjasama dengan pihak kepala SMPN 2 Gunungsari, terutama yang berkaitan dengan tempat pelaksanaan program sebagai masyarakat sasaran. Harapannya adalah bantuan dari pihak sekolah dapat memperlancar program penyuluhan. Ketiga, pelaksanaan program penyuluhan gemar makan ikan pada guru yang dilakukan dalam satu kali pertemuan. Secara bergiliran, anggota tim memberikan materi yang tersusun sesuai di lampiran dan diakhiri dengan sesi Tanya jawab.

\section{Hasil dan Pembahasan}

Kegiatan pengabdian masyarakat yang difokuskan pada pentingnya mengkonsumsi ikan untuk kesehatan dan kecerdasan anak di SMPN 2 Gunungsari Lombok Barat ini dapat berjalan lancer sesuai dengan yang direncanakan. Pada saat sosialisasi gemar makan ikan dihadapan para guru SMPN 2 Gunungsari, antosiasme para guru sebagai kelompok sasaran sangat tinggi, hal ini dibuktikan dengan banyaknya pertanyaan yang muncul terkait materi yang disajikan.

Selama ini mereka belum pernah mendapatkan materi sosialisasi ikan sebagi sumber makanan yang paling baik dan aman untuk kesehatan. Selama ini mereka banyak mendapatkan materi tersebut melaui media terutama media elektronn Televisi, itupun sepintas/sekilas saja mereka dapatkan. Berbeda sekali tingkat pemahaman mereka ketika kami menyampaikan materi tersebut, 
Tim menyampaikan materi secara detail dan menarik, sehingga mereka sangat antusias bertanya dan memberikan apresiasi tinggi kepada tim.

Kegiatan pengabdian semacam ini dapat dinilai sebagai kegiatan yang sangat bermanfaat, tidak hanya bagi guru, tetapi sangat bermanfaaat untuk siswa, orang tua dan keluarga siswa, serta masyarakat luas dalam upaya meningkatkan derajat kesehatan masyarakat melalui gemar makan ikan.

Upaya pemeliharaan kesehatan masyarakat saat ini merupakan hal yang perlu mendapat perhatian yang sangat penting oleh pemerintah. Sekitar lima juta balita di Indonesia teridentifikasi kekurangan gizi. Hal ini dikarenakan asupan makanan yang dikonsumsi kurang bergizi dan rendahnya daya beli masyarakat termasuk minimnya ketersediaan bahan pangan serta kurangnya pengetahuan masyarakat tentang pentingnya untuk menjaga kesehatan sejak dini hingga masa tua. Gizi merupakan unsur yang sangat penting dalam tubuh. Dengan gizi yang baik, akan membuat tubuh menjadi segar dan dapat melakukan aktivitas dengan baik. Gizi harus terpenuhi sejak masa anak-anak, karena gizi selain penting untuk pertumbuhan badan, juga penting untuk perkembangan otak. Untuk itu, orang tua harus mengerti dengan baik kebutuhan gizi si anak agar anak tidak mengalami kurang gizi dan tidak gampang sakit.

Program gerakan memasyarakatkan makan ikan merupakan program yang dimuali sejak presiden Soeharto sampai saat sekarang ini. Kegemaran makan ikan harus dibiasakan sejak dini, sehinggga anak akan tumbuh sehat. Orang tua juga harus bisa membiasakan anak-anak untuk gemar memakan ikan. Dibanding dengan daging hewan lain, ikan merupakan makanan yang mudah dicerna oleh tubuh, sehingga ikan dapat dikonsumsi oleh semua golongan masyarakat, baik balita, anakanak, remaja dan orang dewasa maupun orang tua. Sebagian besar anak-anak/siswa SMP memiliki pengetahuan tentang pentingnya peningkatan gizi sejak dini masih terbatas, sementara masa anakanak adalah masa pertumbuhan yang membutuhkan asupan gizi lebih agar pertumbuhannya optimal dan meningkatkan kecerdasan pada tiap individu.

Sekolah sebagai salah satu media yang efektif untuk mensosialisasikan pentingnya mengkonsumsi ikan untuk kesehatan dan kecerdasan anak. Sentuhan guru sangat dibuthkan untuk mensosialisasikan gerakan makan ikan karena guru setiap saat dapat menyampaikannya kepada siswa baik ketika sedang mengajar di kelas maupun di luar kelas. Guru di depan para murid sebagai orang yang digugu dan ditiru memiliki peranan yang sangat penting di dalam menyampaikan pesan gerakan makan ikan. Oleh karena itu kegiatan pengadian ini orang pertama yang diberikan pemahaman tentang pentingnya mengkonsumsi ikan untuk kesehatan tubuh adalah guru. Selanjutnya guru diharapkan akan menyampaikannya kepada siswa/murid dan murid akan menyampaikannya kepada orang tua dan keluarga di rumah. Melalui program ini diharapkan kegemaran masyarakat terhadap gemar makan ikan semakin meningkat, sehingga uapaya menciptakan kondisi masyarakat yang sehat dan berkualitas dapat terwujud di masa depan nantinya.

Faktor penghambat dalam melaksanaka kegiatan ini sesungguhnya tidak ada factor yang memberatkan/berarti, namun sosialisasinya ke murid oleh guru yang menjadi Tujuan dari kegiatan pengabdian ini sebagai berikut: mensosialisasikan khasiat penghambat. Guru-guru SMPN 2 Gunungsari memiliki latar belakang pengetahuan yang berbeda dalam memahami peranan ikan laut terhadap penyembuhan berbagai penyakit dan meningkatkan kecerdasan.

Berdasarkan pemamaman yang berbeda tentang manfaat ikan laut untuk keshatan oleh guruguru yang berbeda pengetahuannya, maka penyampaiannya ke siswa juga akan sedikit berbeda, sehingga pemahaman siswa akan sedikit berbeda juga, dan seterusnya kepada orang tua, keluarga dan masyarakat. Mestinya sosialisasi gerakan memasyarakatkan makan ikan ini diberikan juga ke para siswa, selain guru oleh Tim Ahli yang sama, sehingga pemahaman mereka tentang materi yang diberikan oleh penceramah dapat diterima secara utuh dan benar.

\section{Kesimpulan}

Berdasarkan pada hasil dan proses pelaksanaan kegiata pengabdian ini, dapat disimpulkan bahwa 1) Upaya pemeliharaan kesehatan masyarakat saat ini merupakan hal yang perlu mendapat perhatian yang sangat penting oleh pemerintah. Hal ini dikarenakan asupan makanan yang dikonsumsi kurang bergizi dan rendahnya daya beli masyarakat 
termasuk minimnya ketersediaan bahan pangan serta kurangnya pengetahuan masyarakat tentang pentingnya untuk menjaga kesehatan sejak dini hingga masa tua. 2) Kegiatan pengabdian gemar makan ikan bagi guru-guru sangat bermanfaat, dan masih sangat dibutuhkan. Mengingat kegiatan ini adalah kegiatan pertama di SMPN 2 Gunungsari, sehingga sangat wajar respon guru-guru sebagai khalayak sasaran mendaptkan apresiaisi yang tinggi

\section{Saran}

Dari pengalaman yang diperoleh selama proses kegiatan pengabdian dilakukan, anggota tim menyarankan: 1) Semua pihak terkait, terutama perguruan tinggi melalui Lembaga penelitian dan Lembaga Pengabdian Kepada Masyarakat perlu melakukan penelitian dan pemberdayaan masyarakat dengan program Gemar makan ikan sejak zama orde baru sampai saat ini. 2) Dinas pendidikan kabupaten harus menjalin kerjasama yang baik dan berkelanjutan dengan Dinas kelautan dan Perikanan, dan Dinas Kesehatan untuk dapat membuat dan melaksanakan program pemberdayaan dan sosialisasi gemar makan melalui sekolah, sehingga nantinya program ini dapat meningkatkan derajat kesehatan masyarakat khususnya guru dan siswa.

\section{Daftar Pustaka}

Calder, P.C. 2012. The role of marine omega-3 (n3) fatty acids in inflammatory processes, atherosclerosis and plaque stability. Mol Nutr Food Res., 56(7):1073-1080.

Deckelbaum, R.J., and T. Torrejon. 2012. The omega-3 fatty acid nutritional landscape: health benefits and sources. J. Nutr., 142(3): 587S-591S.

Dorval, E. K. Piner, L. Robertson, C. S. Reiss, B. Javor, R. Vetter. 2011. Temperature record in the oxygen stable isotopes of Pacific sardine otoliths: Experimental vs. wild stocks from the Southern California Bight. J. Exp. Mar. Biol. and Ecol., 397: 136-143.

Monroig Ó, Li Y and D.R Tocher. 2011. Delta-8 desaturation activity varies among fatty acyl desaturases of teleost fish: High activity in delta-6 desaturases of marine species. Comparative Biochemistry and Physiology Part B: Biochemistry and Molecular Biology, 159(4): 206-213.

Rebah, F. B., A. Abdelmouleh, W. Kammoun and A. Yezza. 2010. Seasonal variation of lipid content and fatty acid composition of Sardinella aurita from the Tunisian coast. Abstract. Journal of the Marine Biological Association of the United Kingdom, 90(03): 569-573.

Sayanova, O., R.P. Haslam, M.V.Calerón, N.R. López, C.Worthy, P. Rooks, M.J. Allen, J.A. Napier. 2011. Identification and functional characterisation of genes encoding the omega-3 polyunsaturated fatty acid biosynthetic pathway from the coccolithophore Emiliania huxleyi. Phytochemistry, 72(7): 594-600. 